Paedagogia Christiana

2/30 (2012) - ISSN 1505-6872

Katarzyna Tomaszek*

Stanistawa Tucholska**

Nowy Sącz

\title{
Psychospołeczne następstwa poczucia alienacji u młodzieży
}

\section{Wprowadzenie}

Okres adolescencji jest czasem intensywnego rozwoju osobowości, w którym młody człowiek zaczyna wytyczać własną drogę życiowa, poszukuje odpowiedzi na szereg pytań, między innymi o to, kim jest i ku czemu zmierza. Odkrywa sens własnej egzystencji i wyznacza mniej lub bardziej odległe cele do realizacji. Jest to również czas kształtowania własnego systemu wartości. Budując go, adolescent konfrontuje preferowane przez siebie wartości z tymi, które proponuje społeczeństwo. Proces ten nie zawsze przebiega spokojnie i łagodnie, gdyż nie sprowadza się on tylko do prostej asymilacji obowiązujących $\mathrm{w}$ społeczeństwie norm, zasad i standardów. Często wspomniana konfrontacja przeradza się w kontestację, co sprawia, że adolescencja jest w literaturze określana jako czas buntu i konfliktów czy też sprzeciwu i stresu'. Ważnym zadaniem w tym okresie rozwojowym jest określenie własnej tożsamości. Dokonuje się ono między innymi na drodze

* Dr Katarzyna Tomaszek jest adiunktem Wydziału Psychologii Wyższej Szkoły Biznesu - National-Louis University w Nowym Sączu.

** Dr hab. Stanisława Tucholska, prof. WSB-NLU, pracuje na Wydziale Psychologii Wyższej Szkoły Biznesu - National-Louis University w Nowym Sączu.

${ }^{1}$ I. Obuchowska, Adolescencja, w: B. Harwas-Napierała, J. Trempała (red.), Psychologia rozwoju człowieka, Warszawa 2003, s. 163-201. 
nabywania nowych umiejętności, zdobywania coraz bogatszych doświadczeń, rozwijania nowych kierunków zainteresowań, ale również poprzez wypracowywanie własnego systemu wartości, co często łączy się z kwestionowaniem czy też negacją obowiązujących zasad, reguł i kwestionowaniem autorytetów.

Obserwowany w tym okresie intensywny rozwój społeczny sprawia, że szczególnego znaczenia nabiera środowisko rówieśnicze. Przebywanie nastolatka w większej grupie ubogaca go emocjonalnie, gdyż umożliwia wymianę „twarzą w twarz" i sprzyja nawiązywaniu głębokich więzi uczuciowych z osobami spoza rodziny. Bezpośrednie kontakty rówieśnicze dają również możliwość wyboru obiektu miłości, a więc kogoś, kto staje się wyjątkowo bliski i ważny.

Młody człowiek, by odpowiedzieć na nurtujące go pytania i wytyczyć własną drogę życiowa, potrzebuje zarówno bliskich relacji z rodziną i rówieśnikami, jak również czasu na przemyślenia wielu spraw i intelektualną refleksję, a to w jakimś stopniu wymaga odosobnienia. Ważna jest w tym okresie otwartość na kontakty, ale również szczególnego znaczenia nabiera potrzeba zakreślenia granic dla własnego ja. Wymaga to nauczenia się zaspokajania dwóch pozornie sprzecznych potrzeb, jakimi są potrzeba bliskości z innymi oraz potrzeba autonomii, niezależności czy też samostanowienia. Wypracowana w tym okresie umiejętność zrównoważonego działania w płaszczyźnie tych dwóch tendencji: bycia razem czy też oddalenia, wyizolowania się z relacji społecznych, jest ważna dla psychospołecznego funkcjonowania człowieka w późniejszych fazach rozwojowych. Dostrzegł to Erikson, który w swojej teorii przyjmuje, iż okres adolescencji wiąże się z koniecznością przezwyciężenia kryzysu, określanego jako: intymnośćizolacja ${ }^{1}$.

Alienacja obserwowana w początkowej fazie adolescencji może być postrzegana jako okoliczność sprzyjająca kształtowaniu się tożsamości jednostki i osiaganiu przez nią autonomii. Fromm zwraca uwagę, że przezwyciężenie jej jest elementem usprawniającym podmiot i daje możliwość uzyskania odpowiedzi na ważne pytania natury egzystencjalnej². Podobne stanowisko przyjmuje Tillich, który uważa, iż pewien poziom samotności jest potrzebny czy nawet konieczny do kształtowania osobistej dojrzałości i integracji ${ }^{3}$.

Erikson podkreśla, że nastolatek, który już odnalazł swą tożsamość, pragnie złączenia jej z tożsamością innych. Czuje się przygotowany do intymności, co oznacza, że jest gotów do zaangażowania w określone związki

${ }^{1}$ E. H. Erikson, Dzieciństwo i społeczeństwo, Poznań 2000.

2 E. Fromm, Zdrowe społeczeństwo, Warszawa 1996.

${ }^{3}$ P. Tillich, Męstwo bycia, Poznań 1994. 
i wspólnoty, i jest przekonany, że sprosta temu zaangażowaniu, nawet jeśli wymagać ono będzie znacznych poświęceń i kompromisów. Pojawiające się u dorastającej młodzieży zachowania wspólnotowe nacechowane otwartością, serdecznością, tkliwością i bliskością wskazują na konstruktywne rozwiązanie kryzysu związanego z intymnością i izolacją. Natomiast ich brak może być związany z poczuciem głębokiej izolacji, a w dłuższej perspektywie może prowadzić do zamknięcia się w sobie i pełnego wyizolowania ${ }^{4}$.

Choć tendencje alienacyjne młodzieży są powszechne i w płaszczyźnie rozwojowej zrozumiałe, to zwraca się też uwagę, że winny one mieć charakter przejściowy ${ }^{5}$. Równocześnie przyznaje się, że wyobcowanie pociaga za sobą pewne negatywne konsekwencje dla psychospołecznego funkcjonowania nastolatka. Są one tym większe, im poczucie wyalienowania jest bardziej nasilone, trwa dłużej, a nastolatek nie ma wystarczającej sieci wsparcia społecznego, umożliwiającej mu przezwyciężenie doświadczanych trudności i rozwiązanie kryzysu, dotyczącego intymności-izolacji ${ }^{6}$. Istotą alienacji jest doznawanie poczucia odłączenia czy obcości wobec jakiegoś obszaru rzeczywistości zewnętrznej czy wewnętrznej podmiotu.

Negatywne następstwa dotyczą głównie poznawczej oceny świata oraz emocjonalnego ustosunkowania się do siebie i innych. Niektórzy autorzy zwracają uwagę, że alienacja, szczególnie wówczas gdy jest zbyt nasilona, może powodować również trudności natury zdrowotnej (badania między innymi Kmiecik-Baran ${ }^{7}$, Piotrowskiego ${ }^{8}$, Dołęgi $\left.{ }^{9}\right)$. Nie można w tym miejscu pominąc doniesień tych autorów, którzy podkreślaja, iż jedną z przyczyn zachowań dewiacyjnych i autoagresywnych młodzieży jest doświadczanie poczucia wyobcowania i braku bliskich, satysfakcjonujących relacji interpersonalnych (por. Piotrowski i Zajączkowski ${ }^{10}$ ).

${ }^{4}$ E. H. Erikson, Dopetniony cykl życia, Poznań 2002.

${ }^{5}$ M. R. Brown, K. Higgins, K. Paulsen, Adolescent alienation: What is it and what can educators do about it?, „Intervention in School \& Źlinic” 39 (2003), s. 3-7.

${ }^{6} \mathrm{~K}$. Tarquin, C. Cook-Cottone, Relationships among aspects of student alienation and self concept, „School Psychology Quartaly” 23 (2008), s. 16-25.

${ }^{7}$ K. Kmiecik-Baran, Poczucie alienacji. Treść i charakterystyka psychometryczna, „Przegląd Psychologiczny" 4 (1993), s. 461-480.

${ }^{8}$ P. Piotrowski, Zachowania dewiacyjne i aktywność prospołeczna młodzieży a poczucie alienacji, „Szkoła Specjalna” 1 (2001), s. 16-27.

9 Z. Dołęga, Poczucie samotności a zachowania agresywne uczniów, „Psychologia Wychowawcza" 2 (1999), s. 146-153.

${ }^{10}$ P. Piotrowski, K. Zajączkowski, Poczucie alienacji chłopców z grupy wysokiego ryzyka. Efektywność oddziaływań profilaktycznych, „Psychologia Wychowawcza” 5 (1999), s. $428-441$. 
Problem wyobcowania, odnoszący się zarówno do wymiaru kontaktów interpersonalnych, jak i wewnętrznych obszarów własnej osoby, nabiera szczególnego znaczenia w świetle badań Watanabe przeprowadzonych w Japonii, które wskazują na znaczący wpływ samotności w sensie psychicznym na wzrost ryzyka zachowań samobójczych w każdej grupie wiekowej, a w okresie dojrzewania w szczególności. Ryzyko to jest szczególnie wysokie, gdy poczuciu izolacji towarzyszy przekonanie o byciu odrzuconym (doświadczenie anomii) $^{11}$. Płużek ponadto zauważa, że istotnym motywem podejmowania prób samobójczych jest poddawanie w wątpliwość sensu własnej egzystencji ${ }^{12}$. Jeśli przyjmie się, jak czyni to Seemann, że poczucie osamotnienia i bezsensu są wymiarami poczucia alienacji, to problem doświadczania stanu wyobcowania okazuje się być istotnym czynnikiem ryzyka zachowań suicydalnych, co znajduje potwierdzenie nie tylko w badaniach naukowych, ale również w praktyce klinicznej ${ }^{13}$. Dane statystyczne wskazują, że młodzież jest jedną z grup najbardziej zagrożonych zachowaniami autodestruktywnymi ${ }^{14}$.

Przeprowadzone przez Tomaszek badania 199-cio osobowej grupy adolescentów wskazuja, iż około $50 \%$ badanych (113 osób) doświadczało wyalienowania w stopniu umiarkowanym i wysokim ${ }^{15}$. Woźniak-Krakowian i Ortenburger podkreślają, że poczucie alienacji doświadczane przez badaną młodzież jest zjawiskiem powszechnym, a tłumaczyć to można szczególnym momentem ontogenezy a więc pewnymi prawidłowościami rozwojowymi i kryzysem normatywnym ${ }^{16}$. W badanej przez nich grupie u około $70 \%$ nastolatków widoczna była alienacja. Wysokie wskaźniki tej zmiennej w grupie młodzieży uzyskali również: Piotrowski ${ }^{17}$, Dołęga ${ }^{18}$ i Miluska ${ }^{19}$. Te dane epidemiologiczne wskazują, że alienacja młodzieży staje się zagadnieniem ważnym zarówno w płaszczyźnie teoretycznej, jak i praktycznej.

${ }^{11}$ R. O’Connor, N. Sheehy, Zrozumieć samobójcę, Gdańsk 2002.

12 Z. Płużek, Psychologia pastoralna, Kraków 1994.

${ }^{13}$ K. Kmiecik-Baran, Poczucie alienacji: destruktywne i konstruktywne sposoby minimalizacji, Gdańsk 1995.

${ }_{14}$ M. Jarosz, Samobójstwa, Warszawa 1997.

${ }^{15}$ K. Tomaszek, Korelaty osobowościowe poczucia alienacji u młodzieży, Lublin 2007, Archiwum KUL (niepublikowana praca magisterska).

${ }^{16}$ A. Woźniak-Krakowian, D. Ortenburger, Poczucie alienacji młodzieży i jej konsekwencje, ,Tolerancja” 10 (2003), s. 273-283.

${ }_{17}$ P. Piotrowski, dz. cyt., s. 16-27.

18 Z. Dołęga, dz. cyt., s. 146-153.

19 J. Miluska, Społeczne wyznaczniki i konsekwencje sytuacji alienujacej, Poznań 1983. 
Poczucie alienacji rozumiane jest najczęściej jako subiektywny stan osoby charakteryzujący się obecnym u podmiotu przekonaniem lub poczuciem, że pewne istotne obszary rzeczywistości są obce. Zgodnie z teorią Seemana, w alienacji wyodrębnić można pięć następujących wymiarów: poczucie bezsilności, poczucie bezsensu, poczucie anomii, poczucie osamotnienia (izolacji) oraz poczucie samowyobcowania ${ }^{20}$. Przy dużym ich nasileniu mogą one znacząco modyfikować psychospołeczny rozwój i funkcjonowanie nastolatka ${ }^{21}$.

\section{Psychospołeczne następstwa doświadczania wyalienowania}

Doświadczenie własnego wyalienowania prowadzi do szeregu negatywnych konsekwencji. Korzeniowski ${ }^{22}$ wskazuje, że reakcja na doświadczenie wyalienowania, będąca próbą poradzenia sobie z nim, może obrać kierunek wewnętrzny i dotyczyć struktury ,ja”. Wyraża się to apatia, poczuciem bezcelowości, czasami nawet rozpaczy. Może też być skierowane na struktury społeczne, czego wyrazem jest jawnie okazywany sprzeciw, bunt, wzrost krytycyzmu i odrzucenie. Podobnie Kmiecik-Baran ${ }^{23}$ wyodrębnia dwa sposoby reagowania na doświadczoną alienację: destruktywny i konstruktywny. Autorka ukazuje i analizuje procesy towarzyszące alienacji w następujących sferach: poznawczej i emocjonalnej, społecznej, psychicznej, somatycznej. Zostaną one poniżej zwięźle omówione.

\section{Poznawcze i emocjonalne funkcjonowanie jednostki wyalienowanej}

Osoby wyalienowane, w świetle badań psychologicznych prowadzonych przez McClosky i Schaar, cechują się małą wiedzą o obowiązującym systemie społeczno-politycznym, niskim zainteresowaniem kulturą i ogólnie niską aktywnością intelektualną. Często współwystępuje z tym skłonność do myślenia magicznego, wiara w zjawiska paranormalne, wróżby, proroctwa i jasnowidztwo. Osoby z dużym poczuciem alienacji często doświadczają trudności w rozwiązywaniu problemów logicznych i podejmowaniu decyzji, nie potrafią myśleć w sposób uporządkowany, zdyscyplinowany a zarazem

${ }^{20} \mathrm{~K}$. Korzeniowski, $O$ dwóch psychologicznych podejściach do problemu alienacji. Próba syntezy, „Przegląd Psychologiczny” 1 (1990), s. 121-145.

${ }^{21}$ K. Kmiecik-Baran, Poczucie alienacji. Treść, s. 461-480.

${ }^{22}$ K. Korzeniowski, Poczucie podmiotowości-alienacji politycznej: uwarunkowania psychospoteczne, Poznań 1991.

${ }^{23}$ K. Kmiecik-Baran, Poczucie alienacji: destruktywne. 
giętki. Odznaczają się sztywnością i obsesyjnością zachowań oraz prezentują globalny, nie dość wnikliwy styl funkcjonowania poznawczego ${ }^{24}$.

W sferze emocji cechują się wysokim poziomem lęku oraz skłonnością do przeżywania głównie negatywnych stanów uczuciowych. Taki koloryt emocjonalny można wiązać z innym cechami stwierdzonymi u nich, szczególnie zaś: niską samoocena, tendencją do obwiniania się, poczuciem własnej nieadekwatności, niezadowoleniem z własnego życia, poczuciem osamotnienia. Osobiste sytuacje, w jakich się znajdują traktują na ogół jako przykre, nie poddające się zmianom, a otoczenie jako zagrażające. Taki styl postrzegania rzeczywistości łączy się często z ich brakiem tolerancji na słabości innych oraz tendencją do autorytaryzmu i totalitaryzmu.

Kmiecik-Baran podsumowała wyniki różnych badań psychologicznych nad osobowościowymi korelatami alienacji i stwierdziła istnienie wyraźnego związku introwersji, braku pewności siebie oraz spadku odporności psychicznej z doświadczaniem wyalienowania ${ }^{25}$. Poszukując źródeł i patomechanizmów powyższych trudności, psychologowie stoją na stanowisku, że są one efektem znaczącej redukcji wiązań społecznych, tak ważnych dla rozwoju psychospołecznego nastolatków. Słuszność takiego stanowiska została potwierdzona wynikami badań, które przywołują i analizują Jakubik i Kraszewska ${ }^{26}$. Autorzy podkreślają, że poczucie alienacji w ogólnym jej poziomie, jak również w wymiarach: poczucia bezsilności, poczucia bezsensu, samowyobcowania i poczucia izolacji korelują z cechami osobowości, które odzwierciedlają trudności w kontaktach interpersonalnych i w przystosowaniu się do otoczenia społecznego.

Piotrowski i Zajączkowski badali młodzież należącą do grup przejawiających zachowania dewiacyjne i trudności w przystosowaniu się do otoczenia. W świetle ich badań młodzież z tych grup cechowała się wyższym wyalienowaniem niż ich rówieśnicy z grupy kontrolnej, z czym łączył się również niższy poziom samooceny. Różnice powyższe obejmują wszystkie wskaźniki mierzone w trakcie badania, to jest samoocenę globalną, samoocenę w zakresie cech intelektu, samoocenę w zakresie pozostałych wymiarów, między innymi w zakresie cech najważniejszych czy cech najmniej ważnych. Osoby doświadczające poczucia alienacji charakteryzowały się ponadto znaczną rozbieżnością pomiędzy tym, jakie są (,ja realne"), a tym jakie chciałyby być (,ja idealne"). Według nich najistotniejszymi są właściwości intelektualne, co jednak w ich przypadku nie idzie w parze z sukcesa-

24 Tamże.

25 Tamże.

${ }^{26}$ A. Jakubik, E. Kraszewska, Zespół alienacyjny u mężczyzn uzaléznionych od alkoholu, „Alkoholizm i Narkomania” 1 (2002), s. 95-106. 
mi w środowisku szkolnym ${ }^{27}$. Z dotychczas prowadzonych badań wynika, że zdecydowana większość młodzieży wyalienowanej przeżywa różnego typu trudności z przystosowaniem się do standardów szkolnych i doświadcza niepowodzeń edukacyjnych. Osterman, próbując wyjaśnić tę prawidłowość, zwraca uwagę, iż młodzież do efektywnej pracy potrzebuje poczucia bliskości i wspólnoty klasowej, stąd zrozumiałe są niskie osiągnięcia uczniów wyobcowanych ${ }^{28}$.

Ponadto doświadczanie wyalienowania wiąże się z zewnętrznym poczuciem kontroli i skłonnością do percypowania osiaganych sukcesów w kategoriach efektu działania czynników zewnętrznych (szczęście, przypadek) a nie własnej aktywności.

Badania prowadzone przez Tomaszek dostarczyły danych empirycznych wskazujących, iż młodzież z wysokim poczuciem alienacji charakteryzuje się brakiem zwartej i dojrzałej struktury osobowości oraz niską samooceną. Szczególnie nasilona jest u nich tendencja do zachowań neurotycznych, z czym wiążą się trudności w kontroli emocji, duża labilność oraz stosowanie mało efektywnych sposobów radzenia sobie ze stresem. Jednocześnie powyższym trudnościom towarzyszy niski próg frustracji, co dodatkowo naraża osoby wyalienowane na doświadczanie przykrych emocji, które z racji ich skłonności do zamykania się w sobie są kumulowane i thumione, a więc są trudne do kontroli. Odreagowanie wewnętrznych napięć przybiera u nich często formę zachowań dewiacyjnych, aspołecznych czy autodestruktywnych ${ }^{29}$. Wyalienowani młodzi ludzie z niskimi kompetencjami emocjonalnymi, interpersonalnymi i zaradczymi, nierozumiejący własnych mechanizmów działania a ponadto nierozumiani przez otoczenie, są podatni na marginalizację, co dodatkowo zwiększa ich izolację społeczną. Trudności adaptacyjne, jakich doświadczają, często prowadzą do stanów depresyjnych z nasilonymi komponentami beznadziejności i bezradności.

\section{Sfera kontaktów społecznych u osób wyalienowanych}

Osoby wyalienowane cechują się zmniejszoną ogólną aktywnością, obejmującą także relacje społeczne. W pewnym stopniu może mieć to związek z postrzeganiem otoczenia, jako silnie zagrażającego czy wrogiego. W tym kontekście nie dziwi ich negatywna ocena świata, który postrzegają

27 P. Piotrowski, K. Zajączkowski, dz. cyt., s. 428-441.

${ }^{28}$ K. F. Osterman, Students need for belonging in the school community, „Review of Educational Research" 70 (2000), s. 323-367.

${ }^{29}$ K. Tomaszek, dz. cyt. 
jako miejsce, gdzie panuje niesprawiedliwość. Te negatywne poznawcze reprezentacje otoczenia rodzą tendencje do odgradzania się od świata, a w niektórych przypadkach nawet wrogości względem niego ${ }^{30}$. Kmiecik-Baran, odwołując się do prac Russel, łączy poczucie alienacji z:

1. Lękiem społecznym, niskim poczuciem godności własnej, nieśmiałością, tendencją do zamykania się w sobie i brakiem pewności siebie. Zmienne te wpływają negatywnie na poziom zaradności społecznej podmiotu.

2. Nieprzejawianiem postawy altruizmu, brakiem bliskich więzi rodzinnych, brakiem przyjaciól, zależnością od innych, brakiem zaufania. Zmienne te wpływają na naturę relacji z innymi.

3. Zewnętrznym poczuciem kontroli i zewnątrz-sterownością, brakiem wyraźnie sprecyzowanych celów życiowych, brakiem wiary i przekonań osobistych. Zmienne te warunkują mało aktywny udział w życiu społecznym $^{31}$.

Podobne wnioski wysunął Piotrowski, który badał związek poczucia alienacji z obecnością u młodzieży zachowań dewiacyjnych i aktywnością prospołeczną. W świetle uzyskanych wyników poziom wyobcowania i alienacji wpływa modyfikująco na zdolność podmiotu do uaktywniania cechy altruizmu, zwiększając jednocześnie ryzyko wystapienia zachowań patologicznych. Autor stwierdza, że źródłem takich postaw są brak akceptacji i niezrozumienie reguł społecznych oraz brak sprecyzowanej hierarchii wartości ${ }^{32}$.

Poczucie alienacji wiąże się ponadto z silnym lękiem, wysokim napięciem mięśniowym, odgradzaniem się od otoczenia, tendencją do zachowań wysyconych irytacją, podejrzliwością, wrogością ${ }^{33}$. Powyższe ustalenia są zbieżne z rezultatami badań nad wyalienowaniem młodzieży prowadzonymi przez Woźniak-Krakowian i Ortenburger ${ }^{34}$. Autorki stwierdzają że wśród młodzieży objętej badaniami poczucie alienacji łączyło się z brakiem pożądanych relacji z ważnymi dla człowieka obszarami świata, jakim są: inni ludzie, normy, wartości, oraz z własną osobą. Zauważają one jednocześnie, że uzyskane wyniki każą uwzględnić niedostateczne wsparcie społeczne, jako istotny czynnik w genezie poczucia alienacji.

Jones przytacza szereg badań świadczących o silnych związkach samotności, będącej istotnym wymiarem alienacji, z niezdolnością nawiązywania bliskich, efektywnych, bo dających poczucie bezpieczeństwa i satysfakcjo-

${ }^{30}$ P. Piotrowski, K. Zajączkowski, dz. cyt., s. 428-441.

${ }^{31}$ K. Kmiecik-Baran, Poczucie alienacji: destruktywne.

${ }^{32}$ P. Piotrowski, dz. cyt., s. 16-27.

${ }^{33}$ K. Kmiecik-Baran, Poczucie alienacji: destruktywne.

${ }^{34}$ A. Woźniak-Krakowian, D. Ortenburger, dz. cyt., 273-283. 
nujących relacji interpersonalnych. Podkreśla on jednocześnie, że kierunek ustalonych prawidłowości nie jest jednoznacznie określony. Nie wiadomo więc, czy nieprawidłowości w sferze kontaktów interpersonalnych są pierwotne, czy wtórne względem omawianego zjawiska ${ }^{35}$. Wśród społecznych korelatów samotności wymienia on: problematyczne skłonności i odczucia. Zalicza do nich głównie deprecjację siebie i pesymizm, niepokój, stany depresyjne, poczucie beznadziejności, wyalienowania, niezrozumienia, pustki, bycia niekochanym i opuszczonym.

Jones, analizując szeroko zakrojone badania młodzieży prowadzone przez Brennan i Auslander, zauważa obecność u osób osamotnionych takich cech i zachowań jak: użalanie się nad soba, poczucie odrzucenia przez bliskich, brak popularności wśród rówieśników, słabe poczucie własnej godności $^{36}$. Taki układ cech i właściwości wskazuje na niskie kompetencje emocjonalne i społeczne osób doświadczających samotności. Charakterystyczne dla nich jest przewidywanie czy wręcz oczekiwanie własnej porażki, co z jednej strony wtórnie zaburza kontakty interpersonalne, $\mathrm{z}$ drugiej zaś rodzi postawę cynizmu i odrzucenia życia w różnych jego wymiarach. Szczególnie istotne i godne podkreślenia są pesymistyczne poglądy młodzieży osamotnionej na temat małżeństwa i rodziny. Towarzyszy im przekonanie, że głównym motywem zawarcia przez nich związku małżeńskiego będzie ucieczka przed własną samotnością, poszukiwanie bezpieczeństwa, możliwość oparcia się na kimś, ewentualnie spełnienie życzeń osób znaczących co do zmiany stanu cywilnego i poddanie się presji otoczenia. Żaden z tych motywów nie jest dojrzałym i w tak inicjowanych związkach trudno prognozować odpowiedzialne pełnienie ról oraz symetrię w podejmowaniu zadań i obowiązków dających radość, szczęście i zapewniających powodzenie.

Badania, przytaczane i analizowane przez Jones, wskazują na widoczną u osób osamotnionych silną koncentrację na sobie, co wtórnie zmniejsza u nich wrażliwość na potrzeby i problemy innych, zaburzając w ten sposób relacje interpersonalne i utwierdzając ich w przekonaniu o niemożności nawiązania kontaktu z osobami z otoczenia i uzyskania odpowiedniego oddźwięku społecznego. Zaburzenia dotyczą także życia czysto towarzyskiego i wiążą się z trudnościami w nawiązywaniu znajomości, przedstawianiu się innym, funkcjonowaniu w grupie, nieodczuwaniu przyjemności ze spotkań towarzyskich. Osoby wyobcowane ujawniają również tendencję do przekraczania oczekiwań związanych z pełnieniem ról społecznych. Obserwuje się $\mathrm{u}$ nich niski poziom wymiany intymnych informacji w relacjach partner-

${ }^{35}$ W. H. Jones, Samotność a zachowania społeczne, „Nowiny Psychologiczne” 4 (1988), s. $38-58$.

36 Tamże. 
skich. Często u tych osób widoczny jest brak własnego zdania w istotnych kwestiach, z czym współwystępuje podatność na wpływy innych. Wyniki badań ujawniają ponadto głębokie uwikłanie osób doświadczających bra$\mathrm{ku}$ satysfakcjonujących relacji interpersonalnych w deprecjonowanie siebie i nieuzasadnione przewidywanie odrzucenia przez innych. Prowadzi to w efekcie do minimalizacji prób nawiązywania jakichkolwiek kontaktów z innymi, wtórnie pogłębiając problem i uruchamiając spiralę strat i niepowodzeń towarzyskich ${ }^{37}$. Autorzy zgodnie podkreślają, że charakterystyczna u osób osamotnionych negatywna postawa do siebie współwystępuje z brakiem pozytywnej postawy do innych (por. Jones ${ }^{38}$, Tarquin i Cook-Cottone ${ }^{39}$ ).

Badania psychologiczne prowadzone przez Dołęgę w grupie uczniów szkół średnich wskazują na związek poczucia samotności (jest ono tu tożsame z wymiarem alienacji) z agresją przejawiającą się ekspansywnymi zachowaniami antyspołecznymi, będącymi sposobem na zwrócenie uwagi na siebie i zaznaczenie swej obecności w środowisku rówieśniczym. Traktuje się je jako niedostosowawcze sposoby przełamania swej izolacji. Negatywne style autoprezentacji i regulowania kontaktów z otoczeniem mogą również wynikać, zdaniem autorki, z wadliwej socjalizacji tych młodych ludzi. Destruktywne sposoby radzenia sobie z trudnościami czy przeciwnościami losu przybierają u nich czasami formę zachowań przestępczych i tendencji do tworzenia wspólnot o destruktywnym charakterze ${ }^{40}$.

Badania Piotrowskiego i Zajączkowskiego wykazały ponadto, że przynależność do destruktywnych grup, będąca formą kompensacji dla jej członków, nie generuje trwałego obniżenia poczucia alienacji ${ }^{41}$. Przytoczone powyżej badania wskazują na agresję fizyczna, jako na dominujący typ agresji w grupie młodzieży wyalienowanej. Wydaje się, że agresję traktują oni jako jeden ze sposobów osiagania założonych celów i ma ona w tym wypadku charakter instrumentalny. Młodzież doświadczająca poczucia alienacji wykazuje ponadto wyższy niż ich zintegrowani z otoczeniem rówieśnicy poziom agresji wyrażanej w postaci buntu czy sprzeciwu skierowanego do dorosłych oraz agresji słownej. Wyniki badań psychologicznych wskazują jednocześnie na niższy poziom poczucia winy w tej grupie. Przytaczane wcześniej badania Woźniak-Krakowian i Ortenburger obejmowały również swym zakresem zachowania agresywne młodzieży wyalienowanej. Uzyskane rezultaty potwierdziły związek alienacji z ogólnym poziomem agresji fizycznej,

\footnotetext{
37 Tamże.

38 Tamże.

39 K. Tarquin, C. Cook-Cottone, dz. cyt., s. 16-25.

40 Z. Dołęga, dz. cyt., s. 146-153.

41 P. Piotrowski, K. Zajączkowski, dz. cyt., s. 428-441.
} 
co tłumaczy się wzrostem negatywnych emocji generowanych doświadczaniem poczucia alienacji. Jednocześnie autorki odnotowały związki alienacji i poczucia samowyobcowania z agresją pośrednią (ukierunkowaną na określoną osobę w sposób nie bezpośredni), jak również agresją bezkierunkową. Wyniki sugerują, iż ogólny poziom poczucia alienacji u młodzieży wykazuje istotny statystycznie związek z ogólnym poziomem agresji, urazą do świata, winą i podejrzliwością, skłonnością do irytacji i negatywizmu ${ }^{42}$.

Według Maya, jednostki wyalienowane tylko fizycznie, a więc w sposób niepełny, moga funkcjonować w otaczającym świecie i pełnić wyznaczone role bez wyraźnych oznak nieprzystosowania. Faktycznie zaś cechuje je niezdolność do nawiązywania bliskich satysfakcjonujących relacji, tendencja do wycofania, którym towarzyszy konstytutywne przeświadczenie o byciu niekochanym, upokarzanym i krytykowanym przez innych ${ }^{43}$. May równocześnie czyni istotną uwagę, że typ schizoidalnego funkcjonowania jest naturalnym sposobem życia w świecie ery technologicznej, w którym obecnie żyjemy ${ }^{44}$. Problem staje się niepokojący wówczas, gdy w środowisku wychowawczym nie ma tendencji do równoważenia deficytów kompetencyjnych, w tym szczególnie społecznych i zaradczych, a brak bezpośrednich więzi upośledza jednostkę, czyniąc ją niezdolną do wysiłku, by odnaleźć siebie i realizować zadania życiowe. Konsekwencje zaś powyższych trudności ujawniają się w jeszcze większym wymiarze, gdy w miejsce pustki egzystencjalnej i chaosu wartości wkracza apatia, bezsilność i poczucie beznadziejności. Tego typu przeżycia i doświadczenia dodatkowo wzmacniają tendencje alienacyjne i moga przybierać ekstremalne formy.

W tym kontekście warto wspomnieć o chorobie cywilizacyjnej występującej u młodych ludzi w krajach dalekiego wschodu, głównie w Japonii i Korei, określanej jako syndrom hikikomori. W języku japońskim słowo „hikikomori” wskazuje na proces oddzielenia się od innych, bądź na osobę, która się odosobniła. Do języka nauki wprowadził je psychiatra Tamaki Saito na określenie zaburzeń o podłożu psychiczno-emocjonalnym polegających na „,całkowitym wyalienowaniu się przez okres większy niż sześć miesięcy”45. Syndrom ten objawia się skrajnym wycofaniem się z życia społecznego, które może trwać bardzo długo, bo nawet kilka lat, i ma formę zamykania się w domu i unikania bezpośredniego kontaktu z ludźmi, nawet z domownika-

${ }^{42}$ A. Woźniak-Krakowian, D. Ortenburger, dz. cyt., s. 273-283.

${ }^{43}$ R. May, O istocie człowieka. Szkice z psychologii egzystencjalnej, Poznań 1995.

${ }^{44}$ Tenże, Milość $i$ wola, Warszawa 1978.

45 J. Watts, Public health experts concerned about „, hikikomori”, "The Lancet” 359 (2002), s. 1131. 
mi. Czasami utrzymywany jest sporadyczny kontakt z matką dostarczającą pożywienia. W ich zachowaniu widoczne są komponenty depresyjne. Większość czasu osoby, u których wystapił ten syndrom, spędzają przed ekranem komputera. Pośredni kontakt ze światem utrzymują za pomocą Internetu (por. Watts ${ }^{46}$, Kary ${ }^{47}$, Bieżańska ${ }^{48}$ ). Hikikomorii dotyczy głównie nastolatków płci męskiej i osób po dwudziestym, rzadziej po trzydziestym roku życia (od 15 do 34 lat). Szacuje się, że cierpi na nie około miliona mieszkańców Japonii ${ }^{49}$. Zaburzenie, o którym mowa, na ogół wiąże się z ostrą reakcją ucieczkową osoby na doznany stres po porażce w szkole czy pracy. Jego pojawienie się thumaczone jest $z$ jednej strony brakiem odporności na presję systemu edukacyjnego lub morderczym kultem pracy, z drugiej zaś deficytami kompetencji zaradczych młodych ludzi lub zbyt ambicjonalnym podejściem do zadań ${ }^{50}$. Skrajna izolacja jest reakcją wtórną do doznanych niepowodzeń czy porażek i w znaczący sposób wpływa na dalsze życie nastolatków, gdyż proces ich leczenia uwikłany jest w cały szereg trudności i niepowodzeń. Bardziej efektywne są wszelkie działania prewencyjne, a szczególnie te, które maja charakter prewencji pierwotnej ${ }^{51}$.

\section{Symptomy zaburzeń psychicznych u osób wyalienowanych}

Poczucie osamotnienia powiązane jest na ogół ze stanami depresyjnymi, nie są to jednak zjawiska tożsame. Badania dostarczają wskaźników świadczących o tym, że u osób depresyjnych źródła przeżywanego cierpienia i bólu są zarówno społeczne, jak i podmiotowe. Osoby osamotnione przyczynę swego cierpienia upatrują zaś w doznanym rozczarowaniu społecznym.

Kmiecik-Baran, opierając się na pracach Peplau i współpracowników, podaje, że skutkiem osamotnienia może być depresja, wycofanie się z życia i zmniejszenie prawdopodobieństwa zaistnienia satysfakcjonujących więzi

46 Tamże.

47 T. Kary, Total Eclipse of Son. Why are millions of Japanese youths hiding from friends and family?, „Psychology Today” 1 (2003).

48 A. Bieżańska, Hikikomori, Miesięcznik Okręgowej Izby Lekarskiej „Puls” 3 (2004).

49 A. Borovoy, Japan 's hidden youths: Mainstreaming the emotionally distressed in Japan, „Culture, Medicine and Psychiatry” 32 (2008), s. 552-576.

50 M. Taylor, Strategies of dissociation: A mimetic dimension to social problems in Japan?, „Anthropoetics” 12 (2006).

51 S. Bamba, W. Haight, The developmental-ecological approach of Japanese child welfare professionals to supporting children's social and emotional well-being: The practice of mimamori, „Children and Youth Services Review” 31 (2009), s. 429-439. 
z ludźmi, ale tylko wtedy, gdy jego źródła traktowane są przez podmiot jako nieusuwalne, stałe, permanentne ${ }^{52}$.

Badania psychologiczne i psychiatryczne wskazują na powiązania pomiędzy poczuciem wyalienowania a takimi zaburzeniami jak lęk społeczny i ogólny; zachowania samobójcze; uzależnienia typu alkoholizm, narkomania, hazard, które pociągają za sobą prawdopodobieństwo zaistnienia konfliktów z prawem (por. Cekiera ${ }^{53}$, Płużek ${ }^{54}$ ). Na marginesie można wspomnieć, że wśród rezydentów szpitali psychiatrycznych odnotowuje się wyższy poziom poczucia alienacji: między innymi badania Jakubik i Piaskowskiej ${ }^{55}$. Kmiecik-Baran, odwołując się do badań Spitz‘a, stwierdza, że poczucie alienacji, a więc oderwanie się od ważnych elementów rzeczywistości, generuje działania kompensacyjne, utrudniające czy nawet blokujące zachowanie uznawane za normę, co ostatecznie doprowadza do ,wykolejenia się podmiotu z dialogu”, czyli niezdolności do porozumiewania się. Stan ten może rodzić zaś różne rodzaje patologii ${ }^{56}$. Podobnie May wiąże wyalienowanie z zerwaniem przez podmiot więzi z otoczeniem. Autor stwierdza, że efektem poczucia alienacji mogą być cztery postaci apatii:

- wycofywanie się z życia społecznego, które zapewnia jednostce spokój i obronę przed stresem, powoduje ,wypadnięcie” jednostki z życia,

- apatię wywołaną wewnętrzną niemożnością,

- apatię, której źródłem jest beznadziejność i desperacja i która prowadzi do autorytaryzmu,

- apatię, przejawem której jest odrętwienie i znieczulica, która może rodzić zachowania destruktywne, agresję i przemoc ${ }^{57}$.

Tą ostatnią formą apatii, będąca pochodną wyalienowania, tłumaczy się zbrodnicze czyny nastolatków dokonywane na swoich rówieśnikach, kolegach szkolnych czy nauczycielach.

\section{Zmiany w sferze somatycznej u osób doświadezających wyalienowania}

Stany psychiki człowieka mogą znacząco wpływać nie tylko na jego funkcjonowanie w społeczeństwie, ale i na zdrowie fizyczne. Generowane

${ }^{52}$ K. Kmiecik-Baran, Poczucie alienacji: destruktywne.

${ }^{53} \mathrm{Cz}$. Cekiera, Etiologia i motywacja usitowanych samobójstw. Studium psychologiczne. Warszawa 1975.

${ }^{54}$ Z. Płużek, dz. cyt.

${ }_{55}$ A. Jakubik, K. Piaskowska, Osobowość alienacyjna, a schizofrenia paranoidalna, „Studia Psychologica” 1 (2000), s. 69-80.

${ }^{56}$ K. Kmiecik-Baran, Poczucie alienacji: destruktywne.

${ }^{57}$ R. May, Miłość i wola. 
przez poczucie alienacji negatywne nastawienia i stany emocjonalne mogą przekładać się na wzmożoną podatność na choroby i nieść niebezpieczeństwo przedwczesnej śmierci. Ponadto należy zwrócić uwagę, że alienacja, powodując zaburzenia struktury ,ja”, może prowadzić do lekkomyślnych zachowań i braku rozwagi. Zdaniem specjalistów, dużą niefrasobliwością można tłumaczyć takie zachowania, jak sięganie po używki czy podejmowanie zachowań ryzykownych. Badania nad poczuciem alienacji prowadzone przez Kmiecik-Baran dostarczają danych pozwalających stwierdzić, że destruktywnym przejawem radzenia sobie z poczuciem alienacji u młodzieży jest alkoholizm i narkomania ${ }^{58}$. Można je postrzegać jako formy ucieczki przed doznawanymi negatywnymi emocjami czy też próby regulowania wewnętrznych napięć. W literaturze specjalistycznej zwraca się również uwagę, iż negatywnymi następstwami zdrowotnymi alienacji są takie stany, jak: poczucie rozbicia wewnętrznego, bezsenność, jadłowstręt, zaburzenia szeregu biochemicznych procesów zachodzących w organizmie, zaburzenia pracy układu immunologicznego powodujące wzrost ryzyka zachorowania (por. Kmiecik-Baran ${ }^{59}$, Tomaszek ${ }^{60}$ ). Wydaje się to być zgodne z dotychczasowymi ustaleniami szczególnie psychoanalizy, która wskazuje, iż negatywne emocje, jakich doświadcza podmiot wyalienowany, skierowane na siebie i tłumione jednocześnie w sobie, mogą przyczyniać się do nieprawidłowości w pracy organów wewnętrznych między innymi układu wegetatywnego.

\section{Zakończenie}

Analiza psychologicznych następstw poczucia alienacji wskazuje na istotny wpływ tego doświadczania na psychospołeczne funkcjonowanie nastolatka. Jeśli jest ono nasilone, może modyfikować czy utrudniać rozwój jego osobowości, prowadząc do ukształtowania się osobowości alienacyjnej ${ }^{61}$ czy zespołu alienacyjnego ${ }^{62}$. Przytoczone wyniki badań dostarczają danych wskazujących, iż wyalienowanie łączy się z szeregiem trudności w psychospołecznym funkcjonowaniu młodego człowieka. Podkreślić jednak należy, że osoby doświadczające alienacji w większości nie są jednostkami, których osobowość jest wyraźnie czy głęboko zaburzona, choć zdarzają się i takie przypadki. Tendencje alienacyjne młodzieży na ogół wyni-

\footnotetext{
${ }^{58}$ K. Kmiecik-Baran, Poczucie alienacji: destruktywne.

59 Tamże.

${ }^{60} \mathrm{~K}$. Tomaszek, dz. cyt.

${ }^{61}$ A. Jakubik, K. Piaskowska, dz. cyt., s. 69-80.

${ }^{62}$ A. Jakubik, E. Kraszewska, dz. cyt., s. 95-106.
} 
kają z normatywnych kryzysów tego okresu rozwojowego, stąd nie należy traktować ich skłonności do zamykania się czy odosobnienia jako zachowań wyraźnie patologicznych. Tillich ${ }^{63}$ i Fromm ${ }^{64}$ podkreślali, że pewien poziom samotności jest potrzebny, by kształtować dojrzałość osobistą i osiagnąć wewnętrzną integrację. Wydaje się również, że łączący się z alienacją bunt młodzieży, dotyczący niesprawiedliwych reguł społecznych, może stać się źródłem przemian, tak istotnych dla rozwoju nie tylko własnej osoby, ale i świata. Alienacja może też pomóc nastolatkowi w odkrywaniu własnych ideałów przez uwrażliwienie go na aksjologiczną sferę ludzkiej egzystencji. Izolacja, odosobnienie, brak zgody na to, co powszechne, czy świadomość sprzeczności czynów z przyjmowaną hierarchią wartości, charakterystyczne dla alienacji, to czynniki zmuszające podmiot do pracy zarówno nad światem wewnętrznym, jak i rzeczywistością zewnętrzna. Alienacja byłaby w takim ujęciu elementem procesu poszukiwania realizacji własnych standardów i wartości oraz odnajdywania przez to więzi z sobą samym. Fromm zwraca uwagę, że właśnie świadomość sprzeczności czynów z posiadanymi standardami generuje $\mathrm{w}$ podmiocie przeżywanie negatywnych $\mathrm{i}$ awersyjnych stanów w postaci poczucia alienacji, co może prowadzić do bezsilności, trwałego wyobcowania, bezsensu czy anomii ${ }^{65}$. Poczucie alienacji, będące konsekwencją uświadomienia sobie własnego wyobcowania, może stać się początkiem procesu jego eliminacji z życia podmiotu i poszukiwania wiązań społecznych.

Doświadczenie poczucia alienacji nie musi zatem generować destruktywnego stylu życia, ale może mieć pozytywny wpływ na funkcjonowanie nastolatka. Bunt czy sprzeciw, jaki rodzi się w sytuacji izolacji czy oderwania od ważnych elementów życia, może prowadzić do konstruktywnych zachowań, będących sposobami ochrony przed przeżywaniem wyalienowania. Młodzież najczęściej przezwycięża własną alienację różnymi formami twórczości, uczestniczeniem w konstruktywnych działaniach grupowych, aktywnością religijną, sportową, społeczną czy zawodowa, na przykład podejmowaniem wolontariatu. Rzeczą ważną jest stwarzanie młodym ludziom odpowiednich warunków zewnętrznych do tego typu działań i promowanie takich zachowań. Pomoc adolescentom $\mathrm{w}$ konstruktywnym rozwiązaniu doświadczanych przez nich kryzysów i przezwyciężeniu tendencji alienacyjnych winna być przedmiotem szczególnych starań rodziców, opiekunów, wychowawców i katechetów.

\footnotetext{
63 P. Tillich, dz. cyt.

64 E. Fromm, dz. cyt.

65 Tamże.
} 


\section{Psychosocial Consequences of the Sense of Alienation among Teenagers (Summary)}

The sense of alienation is defined in psychology as a person's estrangement from important areas of functioning. The psychological understanding of this phenomenon includes also a sense of loneliness and withdrawal from social situations. The negative consequences of experiencing alienation in the teenage years involve increased anxiety, self-isolation and self-protection tendencies, emotional coldness, treating others instrumentally, hostility and aggression against others, pessimism, depression and "unreflective conformism". These variables are also regarded as the main risk factors for the emergence of the sense of alienation amongst teenagers. So far, studies have shown significant correlations between the sense of alienation and such behavior as social maladjustment, skipping school, abuse of psychoactive substances, crime and suicidal tendencies. At the same time, the immediate environment is not able to provide the alienated young people with adequate support and assistance. The teenagers who experience alienation are often rejected by their peers. Teachers label them as difficult, rebellious and not very talented, which results in their further marginalization. Consequently, the young alienated people are forced to deal with adaptation difficulties on their own. When they suffer further failures, it affirms their own conviction about their hopelessness and inability to fit in. They often give up further education, which puts this group of teenagers at the risk of social exclusion. 